\title{
Active Fault Determination Methods in Urban Area, Case Study: Application of GPR Method on North Shahre Ray Fault, South of Tehran, Iran
}

\author{
A.Khorsandi Aghai, T.Miyata and J.Yurugi
}

\begin{abstract}
The main objective of this paper is to show GPR (Ground Penetrating Radar) applicable method for active and siesmogenic fault exploration in urban area. The case study has done on north Shahre Ray fault in south of Tehran (Iran). The north Shahre Ray fault on base of exist data is reported as main earthquake sources in Tehran and Ray city. GPR method has applied in three points of active north Ray fault with 100 and $200 \mathrm{MHz}$ frequency antennas in Azim abad village and around. The two points had selected on soil and one on the asphalt where three point locations were on fault along approximately. Field observation of GPR method testing on fault consists of three simple and compound profiles. The compound profile interpretation results shows that fault plan and Tectonic anomaly sharply. The case study conclusions suggest that GPR method is useful and quick tool in compare with other methods for active fault exploration in urban area with average deep fault.
\end{abstract}

Index Terms-GPR method, North Ray fault, active fault identification.

\section{INTRODUCTION}

The active fault locality determination is important and necessary in urban areas. The GPR method is one of active fault exploration surface methods in urban areas that it is without digging. The other applicable methods for fault exploration contains Geoelectric, Geoseismic, trench, borehole, well logging, remote sensing and study on Groundwater surface anomaly. Comparing to other methods, GPR is inexpensive, fast without problems for citizen and sharp in urban area, however it is completive other methods. It is one of the Geophysical methods that developed in1930 [7] and is based on an electromagnetic exploration tool that to be useful in tectonic (fault, fold, joint system...) and undersurface lithology [15]-[9].In hydrogeology, GPR is used for groundwater level movement monitoring [6]. In magnetoelectronic, it is usable for study of the complexity of weathered zone. In general, this method is useful for pipes, cables location distinguishing, monitoring of the water well

Manuscript received May 28, 2011. This work was supported in part by the Power and Water University.

A. Khorsandi Aghai is Faculty member of Power and Water University (e-mail: khorsandi@pwut.ac.ir).

T.Miyat. He is now with the Department of Earth Science, Kobe University, Japan (e-mail: Miyata@kobe-u.ac.jp).

J.Yurugi. Author is with the CTI Engineering CO. Ltd., Japan (e-mail: yurugi@cti.co.jp). field [17], determination of caves and other deep karsts phenomena in carbonates rock [4]-[5] and [12], soil and cements consolidation in civil structure and pipeline seepage determination from surface to a certain deep [16].In addition the GPR method is applied for ice and snow measurement [3].

In this research, GPR technique has applied with 100 and $200 \mathrm{MHz}$ antenna on three sites of active and seismogenoic north Shahre Ray fault at Azim abad village around (Fig 1 and 2). Two sites has selected on the soil (site1 and2) and one site on the asphalt (site 3). Then field operation has done with 100 and $200 \mathrm{MHz}$ antenna on $100 \mathrm{~m}$ long line vertically to fault direct and take out different profiles. In office the field profiles analyzed and compound profiles of three sites are prepared. The results shows active north shahre Ray fault and anomaly zone sharply.

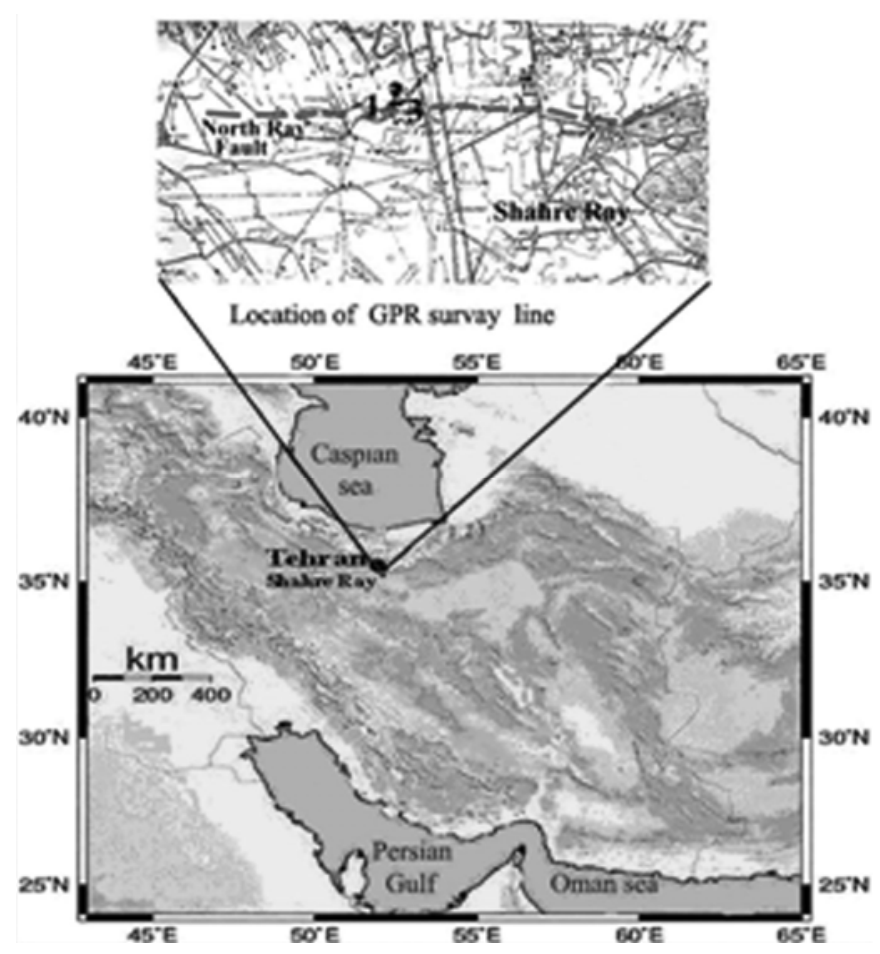

Figure 1. Index map of Iran and Shahre-Ray situation. Above topographic map Shows site of field work (profile1, 2 and 3), (Iran map after IIEES 2000). 


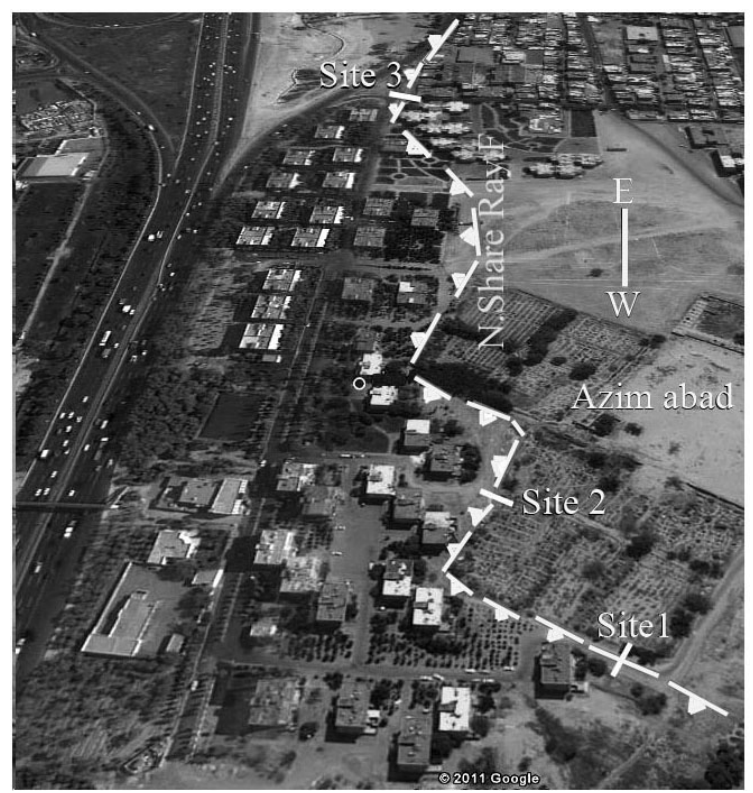

Figure 2. The satellite image of research situation and three profile of GPR method on north Share Ray Fault.

The GPR has defects and virtues due to active fault determination in urban area, to compare other exploration methods that are as follows:

\section{Defects}

1-The GPR method is inexpensive.

2- It is accurate in urban areas.

3 - It is quick method.

4 -It doesn't make problems for other activity in urban area.

Virtues

1- The GPR method is not popular in Iran and other countries that exists active faults in their cities and method instruction may be appear difficult at the beginning.

2- It is useful provided the fault location is identified distance from 10 to $20 \mathrm{~m}$. Therefore application of this method needs to have knowledge of fault situation approximately.

3 -Its penetration depth is average and is not useful for deeper site.

\section{BACKGROUND OF NORTH SHAHRE RAY FAULT}

The north Shahre Ray fault is located on south of Tehran City and north of Shahre Ray City (Fig 1and 2). The length of fault is $16.5 \mathrm{~km}$ and direction is W-E and dip of fault is towards north. This fault has an escarpment between hanging wall and footwall about 2 meters (Fig 3). The north Ray fault is thrust and Shahre Ray depression formed by fault mechanism [1]. The Kahrizak formation (Clays silt of Quaternary) on fault hanging wall thrusted on recent alluvial of north Shahre Ray fault footwall. This fault influenced on groundwater and water table of aquifer is different in two sides of the fault [8]- [10] and [14].

This reason presents the north Shahre Ray fault activity on Tehran plain groundwater that shows it is active fault. The north Shahre Ray fault topography shows an escarpment between hanging (A) and footwall (B) (Fig 3).The escarpment continues along fault and distinguished in site 1 towards west (Fig 2). The local depression was formed by two branch of the north Ray fault in west of Azim- abad village. First time, the north Ray fault introduced by Berberian [2] and then covered by Ray city urban development. Figure 4 shows the geological cross section of Tehran plain and Shahre city. The Seismicity and related Seismicity of North Ray fault quoted from Berberian are shown in table 1 . The available information about the north Ray fault earthquakes (see table 1) indicate that this fault is active and has not strong shaking for a long time (about 1100 years).

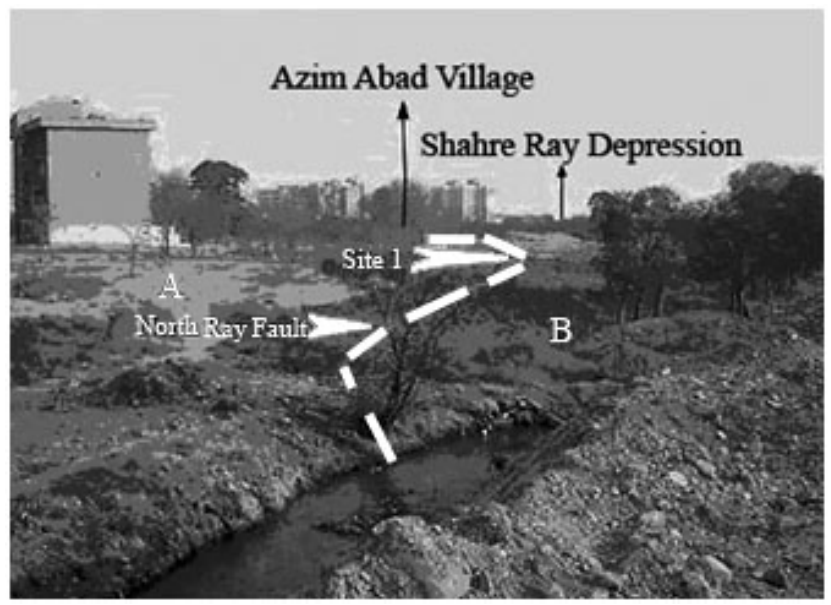

Figure 3. North Ray fault topography and situation of site 1 in west of Azim abad (A=hanging wall, $B=$ footwall).

\begin{tabular}{|c|c|c|c|}
\hline No & Magnitude & Intensity & Date \\
\hline 1 & $\mathrm{Ms}=7.6$ & $I=X$ & 300 B.C \\
\hline 2 & $\mathrm{Ms}=7.1$ & $\mathrm{I}=\mathrm{VIII}$ & 855 A.C \\
\hline 3 & $\mathrm{Ms}=5.3$ & $\mathrm{I}=\mathrm{VII}$ & 864 A.C \\
\hline 4 & ------------ & --------- & 1786 “” \\
\hline 5 & ------------ & --------- & 1966 “” \\
\hline 6 & ------------ & $\mathrm{I}=\mathrm{IV}$ & 1966 “” \\
\hline 7 & ------------ & $\mathrm{I}=\mathrm{IV}$ & 1966 “” \\
\hline 8 & ----------- & $\mathrm{I}=\mathrm{IV}$ & 1966 “” \\
\hline 9 & ------------ & $\mathrm{I}=\mathrm{III}$ & 1970 “” \\
\hline 10 & $\mathrm{Ms}=4.3$ & ------- & 1977 “” \\
\hline 11 & $\mathrm{Ms}=5.2$ & ------- & 1980 “” \\
\hline 12 & $\mathrm{Ms}=5.4$ & $\mathrm{I}=\mathrm{I}$ or II & 1982 “” \\
\hline
\end{tabular}

Therefore it may generate strong earthquake and shaking in future. Similarly study and find position about the north Ray fault is important and useful for future urban area development plane.

So that, north Ray fault located in Shahre Ray and south of Tehran. Urban area of Shahre Ray city is about $12 \mathrm{Km}^{2}$ and populations are more than 500000 and Tehran city populations are more than 10000000 . However north Ray fault located in foreland of folding-thrusting south of Alborz belts due to Huiqi models that shows recent displacement and crust deformation of Ray region, which located in border of north central Iran structural zone (Fig 4).

\section{THE GPR METHOD AND GPR SURVEY LINE IN NORTH RAY FAULT}

The surface Ground Penetrating Radar (GPR) method is comparable to the - reflection seismic method [13]. The 
Source array is an antenna generating a very high-frequency electromagnetic pulse.

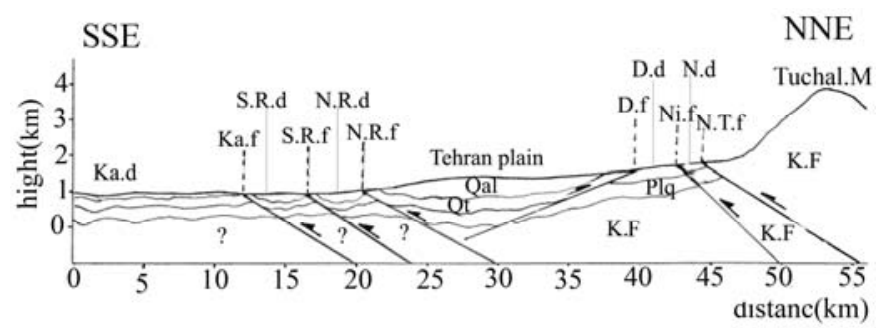

Figure 4. Shematic diagram of geological cross section of deformed wedge of Tehran and Shahre Ray. K.f= Karaj Formation (Miocene),Plq= Hazar dare formation (Pleistocene), $\mathrm{Qt}=$ old alluvial (Quaternary), Qal= recent alluvial, Ka.f=Kahrizak fault, S.R.f=south Ray fault, N.R.f=north Ray fault, D.f $=$ Davudiyeh fault,NI.f $=$ Niavaran fault, N.T.f $=$ north Tehran fault,Ka.d= Kahrizak depression, S.R.d and N.R.d=south and north Ray

Depression, D.d=Davudiyeh depression, N.d= Niavaran depression.

The range of frequency varies from a few tens of $\mathrm{MHz}$ to $\mathrm{GHz}$ frequency. The electromagnetic waves, which penetrate in the ground formation, are recorded by receiving antenna [7]. In north Ray fault we use an antenna that contains source and receiver.

Figure 5 presents the GPR method antenna. It shows antenna that is contains source and receiver (Fig 5-A) and shows antenna with source and receiver separately (Fig 5-B).Also GPR antenna (200, 100, $35 \mathrm{MHz}$ frequency) with different deep penetration was applied for fault distinguishes.

Firstly line of fieldwork is determined in GPR method. Length of line renege from 10 to $20 \mathrm{~m}$ which is divided into small segment of one meter long, then antenna is pulled along the line and electromagnetic wave send into ground formation in predetermined points. The antenna then receives the reflected wave from the ground formation (Figure 5-C). Reflective intensity waves are recorded by Monitoring and different intensity shows anomaly in Underground (Fig 5).

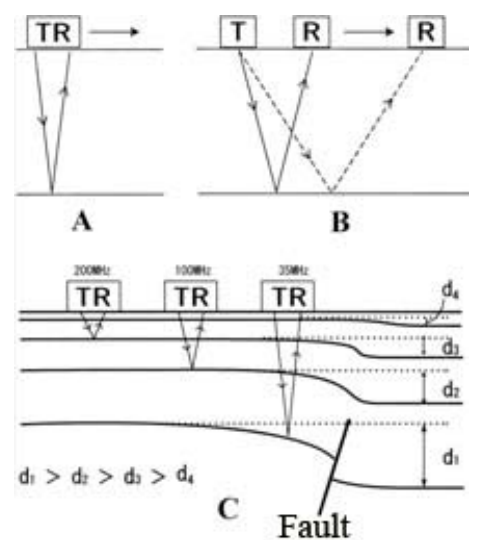

Figure 5. GPR method antenna types (after Miyata, Tanaka, Takada and Shih.2000,[11]). A= antenna with Source and receiver. B=antenna with separated source and receiver. $\mathrm{C}=$ Types of antenna with penetrating deep.

Along north Ray fault three lines determined around Azim- abad Village in northeast of Shahre Ray city (Fig 1and 2).

Site 1(line1) is west of village and site 2 is in the north of village and site 3 is in the east of village. Direction of line is north to south and perpendicular with the north Ray fault direction. The length of line is $20 \mathrm{~m}$ that had 20 segments with one-meter long and center point of line is located on fault approximately. GPR antenna 100 and $200 \mathrm{MHz}$ frequency used in the north Ray fault at three lines.100 and $200 \mathrm{MHz}$ frequency antennas were pulled along line and radar wave penetrated into ground formation and reflected wave recorded by antenna and presented by monitor. The deep of penetration the $100 \mathrm{MHz}$ frequency antenna is $20 \mathrm{~m}$ and $200 \mathrm{MHz}$ antenna frequency is $10 \mathrm{~m}$ maximum.

\section{FIELD OBSERVATION}

Field observation of GPR testing in north Ray fault consists of few profiles. These profiles interoperated after filtration.

\section{A. Simple Profiles 1-3}

The Profile site of 1 it has been obtained from 100 and 200 $\mathrm{MHz}$ frequency antennas with penetration deep from 6 to $20 \mathrm{~m}$. It appears that tectonic anomaly (flexure) in this profile is not narrow and has a width about $5 \mathrm{~m}$ as well as that layers bended and formed a flexure. The fault direction is west to east and fault dip is 70 degree toward north.

The Profile of site 2 has been taken 100 and $200 \mathrm{MHz}$ frequency antenna with penetration deep about 7.5 to $19 \mathrm{~m}$ and shows tectonic anomaly and fault in the near the south of line. The tectonic anomaly is flexure and has similar width. The fault direction is west to east and fault dip is 70 degree towards north.

The Profile of sites 3 has been taken from $100 \mathrm{MHz}$ frequency antennas with penetration deep about 7.5 to $11.3 \mathrm{~m}$. This profile shows anomaly and the fault is near the south of line. The tectonic anomaly is differing layer in both side of fault. The fault direction is west to east and the fault dip is 60 degree towards north. The Profile of sites 1, 2 are on soil surface and profile of site 3 is on asphalt surface.

\section{B. Compound profiles}

The compound or combination profiles prepared from few profiles that have been take from different antenna. The compound profiles are useful for general views and final interpretation.

The compound profiles of site1 prepared from information take from 100 and $200 \mathrm{MHz}$ frequency simple profiles. These profiles show tectonic anomaly and fault that is near the middle of line 1 . The tectonic anomaly is flexure and fault location is the south of anomaly. The fault dip is 70 degree towards north. The fault is reverse and north wall uplifted (Fig 6).

The compound profile of site 2 was on the basis of information were obtained from 100 and $200 \mathrm{MHz}$ frequency antenna. This profile shows tectonic anomaly and fault in middle of anomaly. The tectonic anomaly is flexure and the fault dip is 70 degree towards north. The fault is reverse and north wall uplifted (Fig 7).

The compound profile of site 3 prepared on the basis of information was obtained from $100 \mathrm{MHz}$ frequency antennas. This profile shows fault without anomaly. Fault dip is 60 Degree towards north (Fig 8). 


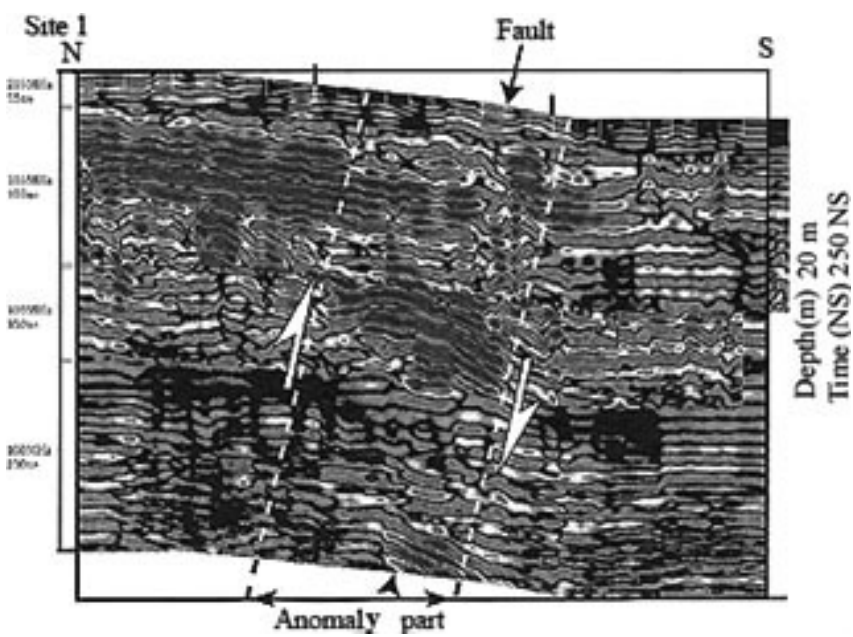

Figure 6. Compound profile of site 1 shows North Ray fault and bended zone anomaly part is fault zone. Depth of Profile is $20 \mathrm{~m}$.

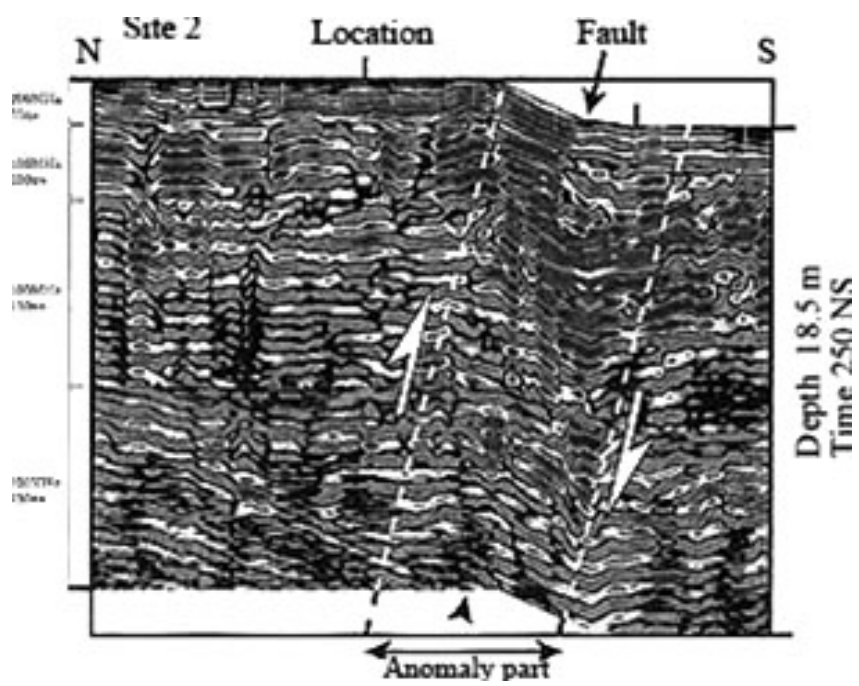

Figure 7. Compound profile of site 2 Shows North Ray fault and bended Zone Depth of profile is $18.8 \mathrm{~m}$

\section{DISCUSSION}

The GPR technique is a very useful method to exploration fault location in urban areas. The buildings and streets or others cover most Faults in urban area with thin or thick cover. When the faults covered by thin layers, the GPR method can be use to distinguishing the situation of hidden faults as a non-distractive technique.

The active faults covered by urban facilities such as buildings, roads etc, so in many of the Iranian city. In many plans we need to learn position of fault in urban areas accurately. The experience in north Shahre Ray fault shows

That the GPR technique is a fast, inexpensive and Economical method for fault identification in Iranian and Other country city where contains fault. For example in Tehran city many active Faults such as Niavaran, Mahmodieh, Shian, kosar, Sorkhe-Hesar, north Tehran, north and south Shahre Ray and South Mehrabad are located in urban area of the Capita l of Iran. We can use GPR method for faults exploration in Tehran and other cites of Iran and another country that is like to Iran. This method is applicable and inexpensive technique for fault identification in urban area.



Fault 7

Figure8. Compound profile of site3 shows North Ray fault line which layer bended near the fault. Depth of profile is $11 \mathrm{~m}$.

\section{CONCLUSION}

The significance of the GPR method application in the north Shahre Ray fault is as follows:

1-The fault characterizes (situation and dip) obtained from the GPR method are the same as those are available from predevelopment of Shahre Ray city.

2-In sites 1 and 2 the tectonic anomaly was observed by the GPR method accurately around natural fault plane.

3-In site 3 the fault was distinguished clearly from top layer the asphalt.

Based on the north Shahre Ray fault, we suggests the GPR Method as an applicable technique for urban environment faults exploration of Iran and semi country. Bay the same token this method application is easy and economical.

\section{REFERENCES}

[1] M. Berberin,"Contribution to the Seismotectonics of Iran" (part II), Geological Survey of Iran, 1976, Report No.39.

[2] M.Berberian, M.Ghorishi, B.Arjang, A. Mohajer. "Seismotectonic and Earthquake-Fault Hazard Investigation In the Tehran Region", Geological Survey of Iran, 1992, No. 56. Report.

[3] J.C. Cook, "Seismic mapping of underground cavities using reflection amplitude", 1965, Geophysies.30.p 527-538.

[4] J.C. Cook, "Proposed monocycle- pulse VHK radar for air bone ice and snow measurement", AIE communications and Electronics, 1960, 51.p 588-594.

[5] J.C. Dubois Borehole radar experiment in limestone: analyze and data processing, 1995, first Breaks .13.2.p 57-67

[6] R.j. Greaves, D.p Lesmes, J.M Lee, "Velocity variation and water content estimated from multi- offset, ground penetrating radar", 1996,Geophysics .6.3.p 683-659

[7] H.M. Jol, "Ground penetrating radar antenna frequencies and transmitter power compared for penetrating depth, resolution continuity", 1995, Geophysical Prospecting, 43, 1.p 693-709

[8] G.I. Knill, K.S Jones, "Groundwater condition in Greater Tehran", 1968, Quart J.Eng.Geol, 1, p 181-194

[9] B.J. Moorman, "Assessing the ability of ground penetrating radar delineates subsurface fluvial lithofacies", M.S Thesies, University of Galary Alberta, 1990.

[10] Ministry of Energy, "Tehran Region Groundwater Balance", 1990, No.44. Report

[11] T. Miyata, Y.Tanaka, S.Takada, and B.J.Shih,:GPR survey for the Chi-Chi earthquake rupture in Taiwan.Proc. $2^{\text {nd }}$ Japan-Taiwan workshop on lifeline performance and Disaster Mitigation, P 170-175, 2002.

[12] R.M. Morey Detection of subsurface cavities by ground penetrating radar .Proceeding Highway Geological Symposium, .p 27-30, 1974.

[13] J.A. Stratton, "Electromagnetic Theory". McGraw hill Book Company, 1941, New York.

[14] J.S Tchalenko,"Seismotectonic Framework of the North Tehran Fault", 1975, Tectonophysics. 29. P 411-420

[15] S. Tillard, .J.C. Dubois, "Influence of lithology on radar echoes, Analysis with respect to electromagnetic parameters and rock anisotropy", $4^{\text {th }}$ International conference on ground penetrating radar. 
Rovaniemi Geological Survay of Finland, special paper 16 .p 95-102, 1992.

[16] C.P.F. Ulriksen, "Application of impulse radar to civil engineering", 1982, Thesis. Lund University of Technology.

[17] R.A. Van Overmeeren, "Monitoring of water well field by Georadar", 56th EAGE Congress, 1994.

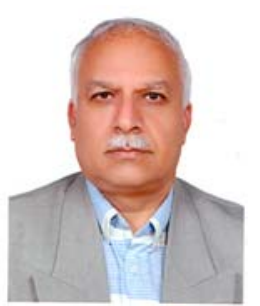

A.Khorsandi Aghai: born in the mashad city in Khorasan province, northeast of Iran in 25/5/1956. Graduated on 1982, 09, 01, Tabriz University, Faculty of Science, Department of Geology, B.C degree on geology. Graduated on 1988, 04, 26, Tehran university, Faculty of Agriculture, Department of irrigation \& reclamination En, MS degree on hydrogeology. Graduated on 2010, 02, 07, Kobe university, graduate school of science, $\mathrm{PhD}$ degree on geology (Hydrogeology). He is faculty member of Power and Water University from 1984 up to now. The relevan experience: Water resources section training deputy, Member of water, technical department of ministry of power and water, Head of water resources section, PWUT water faculty geology, engineering geology, geomorphology and air photograph lab Supervisor. Publications: books are, Principal Applied Hydrogeology Book, 2000, publcated by WPAI, Iran and Qanat in Iran: case study of Tehran qanats Book, 2006, published by Tehran-GIS Centre, Iran. Paper samples : Surface rupture of the Changure Earthquake In northwest of Iran,2002,journal of the Geological Society of Japan (ISI), English , Necessity Storm Water Drainages Due to Rapid extension of Big Cities-Case Study: Storm Water Drainage of Tehran, 5th International Conference Novatech 2004,English , Fault determination due to sinkholes array on lar valley northeast of Tehran ,Iran , Jurnal Acta Carsology (ISI).2007,V 36, Issues 2, P 203-208, The impact of faults on the geomorphology of the earth's crust: Case study of faults impact on the geomorphology of Lar valley, Northeast of Tehran(Iran), Journal of Environmental Geology(ISI), 2008, V 57 , N 3 , p 583 -590 . Presentations are 15. Dr Khorsandi Aghai is Permanent members of water resources Association, IRCOLD, Geological Society of Iran, Engineering Geological Society of Iran, and Iranian Earthquake Engineering Association.

T.Miyata : Date of birth August 21,1974 Japan . Graduated on 1970 Waseda university, BS in geology. Osaka city university 1972, MS in Geology. Dr. of Science :Osaka city university ,1979. Professor of Dep. Of earth and planetary science Kobe university 1992 up now. 